\title{
Marc Depaepe and Lieven D'hulst, with Maartje Theuninck \\ An Educational Pilgrimage to the United States. Travel Diary of Raymond Buyse, 1922
}

\author{
Louvain: Leuven University Press, 2011. 240 pp.
}

\section{Rosa Bruno-Jofré}

Queen's University

This is an outstanding contribution to the history of education and cultural history. The book brings to the public and to historians the content of an obscure binder with scribbles, written on loose sheets, deposited in the Archives of the University K.U. Leuven, archives Raymond Buyse, box 22. It reflects the complex feelings of Raymond Buyse, who would later become a major figure in experimental psychology, during his visit to the United States in 1922. He accompanied Ovide Decroly, the best known representative of new education in Belgium.

The book, published both in English and French in one volume, first situates the reader historically and then offers Buyse's travel notes in the original French with an English translation. In the introduction Depaepe and D'hulst trace the impact of the scientific method on education and its understanding as a means to objectivity and neutrality, introduce the reader to the cult of "measurement" and the ideology of "meritocracy" and the intellectual setting in the United States, and go into some detail on the development of Pedology and Pedotechnics in Brussels. It is a wellresearched background that helps the reader understand the attraction that developments in the United States exerted at the time, the influence that Wilhelm Wundt had on American psychologists at the end of the nineteenth century, and the separation of ends and means that facilitated the integration of experimental pedagogy in a Catholic setting. Buyse was a Catholic and thought of pedagogy as philosophy, a science and an art. Incidentally, Decroly saw pedagogy in the same way, thus, articulating in some way two spheres of interest, mental tests and progressive schools. Depaepe and D'hulst make clear that Buyse and Decroly conceived of educational 
reform as an adaptation of school to modern life. They did not challenge the capitalist meritocratic model. They both had concerns with "equality of mediocrity." Depaepe and D'hulst rightly identify "special education for the abnormal" as the missing link to understand the peculiar situation in Belgium. The negative burden coming from social inadaptability could be translated into a benefit for society by prophylaxis and treatment for which Buyse and Decroly (himself a physician) used the scientific model and had demonstrated an interest in the medico-pedagogical reception of "abnormal" categories.

The mission of the trip was to study and promote the American test movement and the experimental educational psychology sustaining it, and to learn more about the "scientific study" of the child. Decroly and Buyse visited fourteen institutions and met leading figures of the time including an American psychologist specializing in testing, Rudolph Pintner; philosopher John Dewey; Carleton Washburne, known for the Winnetka plan; psychologist Edward Thorndike; and Stanley Hall, leader of the child study movement. The two travelers also became familiar with the StanfordBinet test.

The joint publications that followed the trip reflect the eclectic mix of viewpoints of the authors. Thus, there is an article praising the Park School in Buffalo, as well as a monograph on the practice of mental testing and an introduction to applied statistics in educational research. Depaepe and D'hulst argue that Buyse's contribution in a number of articles is clearly evident.

The second part of the book contains both comments on the style of Buyse's travel notes and the actual text. Buyse wrote his impressions of the trip, as Depaepe and D'hulst noted, going well beyond notes of the meetings by engaging himself in a dialogue with what he observed, giving way to an epistolary voice that conveys his cultural encounter with the various American cities, accompanied by drawings and not without a sense of humour.

This is an exceptional contribution to the history of education in terms of the quality of the introductory analysis and the publication of Buyse's notes, a very difficult task indeed. 